\title{
Genotype Distribution and Prevalence of Human Papillomavirus in Head and Neck Cancer Samples from Istanbul, Turkey
}

\author{
Muammer Osman Köksal ${ }^{1}{ }^{1}$, Başak Keskin Yalçın ${ }^{2}{ }^{(0}$, Fahriye Keskin ${ }^{3, *}$, Sevgi Çiftçi ${ }^{3}$, Ibrahim Yağc1 ${ }^{4}$, \\ Seyhan Özakkoyunlu Hasçiçek ${ }^{5}$, Bora Başaran ${ }^{6}$, Kemal Değer ${ }^{6}$, Ali Ağaçfidan ${ }^{1}$, Alexander Quaas ${ }^{7}$ and \\ Baki Akgül ${ }^{8}$
}

check for updates

Citation: Köksal, M.O.; Yalçın, B.K.; Keskin, F.; Çiftçi, S.; Yağcı, I.;

Hasçiçek, S.Ö.; Başaran, B.; Değer, K.; Ağaçfidan, A.; Quaas, A.; et al. Genotype Distribution and Prevalence of Human Papillomavirus in Head and Neck Cancer Samples from Istanbul, Turkey. Pathogens 2021 10, 1533. https://doi.org/10.3390/ pathogens 10121533

Academic Editors: Anna

Rosa Garbuglia and Maria Gabriella Donà

Received: 27 October 2021

Accepted: 19 November 2021

Published: 23 November 2021

Publisher's Note: MDPI stays neutral with regard to jurisdictional claims in published maps and institutional affiliations.

Copyright: (c) 2021 by the authors. Licensee MDPI, Basel, Switzerland. This article is an open access article distributed under the terms and conditions of the Creative Commons Attribution (CC BY) license (https:// creativecommons.org/licenses/by/ $4.0 /)$.
1 Department of Medical Microbiology, Istanbul Faculty of Medicine, Istanbul University, 34093 Istanbul, Turkey; muammerosmankoksal@istanbul.edu.tr (M.O.K.); aagacfidan@hotmail.com (A.A.)

2 Department of Oral and Maxillofacial Surgery, Faculty of Dentistry, Istanbul University, 34116 Istanbul, Turkey; basakkeskin86@hotmail.com

3 Unit of Microbiology, Istanbul Faculty of Dentistry, Istanbul University, 34116 Istanbul, Turkey; sevgiciftci@gmail.com

4 Department of Otorhinolaryngology \& Head and Neck Surgery, Sisli Hamidiye Training and Research Hospital, University of Health and Science, 34371 Istanbul, Turkey; ibrahimyagcimd@gmail.com

5 Department of Pathology, Sisli Hamidiye Training and Research Hospital, University of Health and Science, 34371 Istanbul, Turkey; shascicek@gmail.com

6 Department of Otorhinolaryngology \& Head and Neck Surgery, Istanbul Faculty of Medicine, Istanbul University, 34093 Istanbul, Turkey; bbasaran@istanbul.edu.tr (B.B.); kdeger@istanbul.edu.tr (K.D.)

7 Institute of Pathology, University Hospital Cologne, 50937 Cologne, Germany; alexander.quaas@uk-koeln.de

8 Institute of Virology, University of Cologne, Faculty of Medicine and University Hospital of Cologne, 50935 Cologne, Germany; baki.akguel@uk-koeln.de

* Correspondence: fahriye.keskin@gmail.com; Tel.: +90-5322059794

\begin{abstract}
Human papillomavirus (HPV)-associated tumors account for a significant proportion of head and neck squamous cell carcinomas (HNSCC) in developed countries. In recent years, there has been a rise of HPV infections associated with HNSCC, especially HPV16, which is the most commonly detected type in oral and oropharyngeal cancers. To investigate the frequency of HPV-driven HNSCC among patients living in Turkey, HPV DNA positivity and p16INK4A expression were assessed in primary tumor biopsies $(n=106)$. Eighteen out of one hundred and six $(19 \%)$ HNSCC tumors showed p16INK4A overexpression, and 26/106 cases (24.5\%) were positive for HPV DNA. Sixteen out of twenty-six samples were positive for both HPV DNA and p16INK4A staining. HPV16 could be isolated from $22 / 26$ samples $(84.6 \%$ ) and was found to be the most frequently detected HPV type. This study represents the largest cohort of Turkish patients with HNSCC characterized according to HPV status and p16INK4A expression. Our data suggest that HPV16 infection, along with smoking, contribute to the development of HNSCC.
\end{abstract}

Keywords: head and neck squamous cell carcinoma (HNSCC); human papillomavirus (HPV); oral cavity; oropharyngeal squamous cell carcinoma (OPSCC); p16INK4A

\section{Introduction}

Squamous cell carcinoma of the head and neck (HNSCC) are anatomically heterogeneous neoplasms originating from mucosal surfaces of the oral cavity, oropharynx, hypopharynx, larynx, and nasopharynx. Approximately 263,000 cases of oral cavity cancer and 135,000 cases of pharyngeal cancer are reported worldwide each year [1]. Head and neck cancer is the sixth most prevalent type of cancer, and there are profound differences in the incidence rates of HNSCC among geographic regions [2]. In general, the number of cancer cases is higher in North America (60.4\%) than in Europe. Within Europe, HNSCC frequency appears to be higher in northern countries $(56.5 \%)$ than in southern countries 
(24.2\%) [3]. Over the past decade, scientists across the globe have observed a steady increase in oropharyngeal squamous cell carcinoma (OPSCC) and a decrease in cancers of the larynx and hypopharynx [4]. OPSCC is diagnosed four times more frequently in males than females in the US [5]. In addition, it is more frequently observed in individuals over the age of 60 [4]. Tobacco and alcohol consumption are among the most important risk factors in the etiology of this cancer type [6]. However, since the 1980s, numerous studies have shown that the human papillomavirus (HPV) can contribute to the etiology of HNSCC types [1,6]. Worldwide, HPV-related OPSCCs increased from $7.2 \%$ in the $1990 \mathrm{~s}$ to $32.7 \%$ in the $2010 \mathrm{~s}$, possibly as a result of changes in sexual behavior [7]. The number of HNSCC diagnoses related to intensive abuse of tobacco and alcohol in the elderly is globally decreasing as a result of the overall decline in tobacco use [8]. By contrast, cases of HPV-related OPSCC mainly induced by HPV16 are on the rise, predominantly among young people in North America and Northern Europe [8,9]. This cancer type is associated with HPV infection as well as sexual behavior (due to oral HPV transmission) $[5,10,11]$. HPV-positive OPSCC is predominantly associated with HPV16 infection, while a relationship has also been observed with several other high-risk HPV types, such as HPV18, HPV33, and HPV52 [12]. Active HPV infection is accompanied by the expression of the viral E7 oncoprotein, which abrogates $\mathrm{pRB}$ functions. The repression of $\mathrm{pRB}$ leads to the overexpression of cellular p16INK4A, which is widely being used as a surrogate marker for HPV oncogenic activity [13-15]. The addition of p16INK4a (p16) immunohistochemistry staining to the HPV DNA test has been recommended in guidelines to improve the accuracy of HPV diagnosis in HNSCC cases [16]. According to cancer statistics data provided by the Turkish Ministry of Health, on average, 1577 newly diagnosed HNSCC cases were recorded annually between 2013-2017, with no significant rise in this period [17]. In recent years, only a limited number of studies have been conducted in Turkey to address the association of HPV infections with HNSCC in Turkish patients [18-24]. The overall aims of this report were therefore to determine the prevalence of HPV infections in HNSCC patients and to describe the HPV type distribution among HNSCC cases.

\section{Results}

A total of 106 specimens were obtained from patients whose ages ranged from 19 to 90 years (mean $=59.7$ years). Primary tumors were located in the oropharynx $(n=72)$ or the oral cavity $(n=34)$. p16INK4A expression was analyzed by performing immunohistochemical staining (IHC). Staining was graded depending on their p16INK4A expression level and pattern. Eighteen HNSCC samples showed p16INK4A overexpression and were considered positive as per the guideline from the College of American Pathologists (CAP) [25]. The p16INK4A evaluations of four samples could not be performed due to quality problems (three HPV DNA positive and one HPV DNA negative). Twenty-six of one hundred and six (24.5\%) HNSCC samples were found to be HPV DNA positive. Out of these patients, 22 (84.5\%) had tested positive for HPV16, 2 individuals had HPV18, and 1 each patient had HPV45 and HPV82. In OPSCC and oral cavity carcinomas, HPV DNA was detected in $20 / 72$ OPSCC cases $(27.8 \%)$ and in $6 / 34$ oral cavity carcinomas (17.6\%) (Table 1). HPV16 and HPV18 co-infection was detected in one tonsillar sample. HPV16 was detected in the vast majority of samples. HPV18, HPV45, and HPV82 were detected in buccal mucosa and two tonsillar samples. From the various tumor subsites, high prevalence rates of HPV DNA were predominantly detected in the palatine tonsils (Table 2). HPV DNA positivity was found to be significantly higher in individuals under 60 years of age $(p=0.024)$. HPV DNA positivity in tumor samples from non-smokers was significantly higher than in those extracted from smokers $(40.6 \%(13 / 32)$ vs. $17.6 \%(13 / 74)$, $p=0.011)$. However, there was no discernible correlation between alcohol consumption and HPV infection. In addition, no relation was found between HPV infection and lymph node status as well as tumor classification $(p>0.05)$. 
Table 1. Demographic variables of the study group.

\begin{tabular}{|c|c|c|c|c|}
\hline Characteristic & Total & HPV DNA+ n (\%) & HPV DNA - n (\%) & $p$ Value \\
\hline Male & $78(73.6)$ & $18(23.1)$ & $60(76.9)$ & \multirow{2}{*}{0.562} \\
\hline Female & $28(26.4)$ & $8(28.6)$ & $20(71.4)$ & \\
\hline Age at diagnosis & 59.7 & 55.2 & 61.15 & \\
\hline Range & 19-90 & $24-70$ & 19-90 & \multirow[b]{3}{*}{0.024 * } \\
\hline$<60$ & $49(46.2)$ & $17(34.7)$ & $32(65.3)$ & \\
\hline$\geq 60$ & $57(53.8)$ & $9(15.8)$ & $48(84.2)$ & \\
\hline \multicolumn{5}{|l|}{ Smoking $(\mathrm{N})^{\mathrm{a}}$} \\
\hline Never & $32(30.2)$ & $13(40.6)$ & $19(59.4)$ & \multirow{3}{*}{$\begin{array}{c}\text { Reference } \\
0.041 * \\
0.028 *\end{array}$} \\
\hline$<400$ & $21(19.8)$ & $3(14.3)$ & $18(85.7)$ & \\
\hline$\geq 400$ & $53(50)$ & $10(18.9)$ & $43(81.1)$ & \\
\hline \multicolumn{5}{|c|}{ Alcohol consumption $(\mathrm{N})^{\mathrm{b}}$} \\
\hline Never & $61(57.5)$ & $17(27.9)$ & $44(72.1)$ & \multirow{3}{*}{$\begin{array}{c}\text { Reference } \\
0.123 \\
0.766\end{array}$} \\
\hline Light & $13(12.3)$ & $1(7.7)$ & $12(92.3)$ & \\
\hline Heavy & $32(30.2)$ & $8(25)$ & $24(75)$ & \\
\hline \multicolumn{5}{|l|}{ Lymph node status (N) } \\
\hline Negative & $47(44.3)$ & $9(19.1)$ & $38(80.9)$ & \multirow{2}{*}{0.250} \\
\hline Positive & $59(55.7)$ & $17(28.8)$ & $42(71.2)$ & \\
\hline \multicolumn{5}{|l|}{ Tumor location $(\mathrm{N})$} \\
\hline Oropharynx & $72(67.9)$ & $20(27.8)$ & $52(72.2)$ & \multirow{2}{*}{0.257} \\
\hline Oral cavity & $34(32.1)$ & $6(17.6)$ & $28(82.4)$ & \\
\hline \multicolumn{5}{|c|}{ Tumor classification $(\mathrm{N})$} \\
\hline $\mathrm{T} 1$ & $24(22.6)$ & $6(25)$ & $18(75)$ & \multirow{4}{*}{0.490} \\
\hline $\mathrm{T} 2$ & $31(29.2)$ & $10(32.3)$ & $21(67.7)$ & \\
\hline T3 & $29(27.4)$ & $7(24.1)$ & $22(75.9)$ & \\
\hline $\mathrm{T} 4$ & $22(20.8)$ & $3(13.6)$ & $19(76.4)$ & \\
\hline \multicolumn{5}{|c|}{ p16 Immunochemistry ${ }^{c}$} \\
\hline Negative & $84(82.4)$ & $7(8.3)$ & 77 (91.7) & \multirow{2}{*}{$<0.001$ * } \\
\hline Positive & $18(17.6)$ & $16(88.9)$ & $2(11.1)$ & \\
\hline
\end{tabular}

${ }^{a}$ Brinkman index: daily cigarettes $x$ years. ${ }^{b}$ Light drinker $\leq 50 \mathrm{~g}$ alcohol per day; Heavy drinker $>50 \mathrm{~g}$ alcohol per day. ${ }^{\mathrm{c}}$ Four samples (three HPV DNA positive and one HPV DNA negative) were of poor quality for p16INK4A staining. * statistically significant.

Table 2. Distribution of HPV types in the various tumor subsite.

\begin{tabular}{|c|c|c|c|c|c|}
\hline Site & Subsite & Specimens & HPV DNA+ (n\%) & HPV DNA - (n\%) & HPV Types \\
\hline \multirow{5}{*}{ Oropharynx } & Palatine tonsils & $38(35.8)$ & $12(31.6)$ & $26(68.4)$ & $16,18,82$ \\
\hline & Base of tongue & $28(26.4)$ & 5 (17.9) & $23(82.1)$ & 16 \\
\hline & Lateral wall & 0 & $0(0)$ & $0(0)$ & - \\
\hline & Posterior wall & 0 & $0(0)$ & $0(0)$ & - \\
\hline & Soft palate & $6(5.7)$ & $3(50)$ & $3(50)$ & 16 \\
\hline \multirow{4}{*}{ Oral cavity } & Oral tongue & $16(15.1)$ & $1(6.2)$ & $15(93.8)$ & 16 \\
\hline & Buccal mucosa-lip & $6(5.7)$ & $4(66.7)$ & $2(33.3)$ & 16,45 \\
\hline & Floor of mouth & $7(6.6)$ & $0(0)$ & $7(100)$ & - \\
\hline & Hard palate & $5(4.7)$ & $1(20)$ & $4(80)$ & 16 \\
\hline Total & & $106(100)$ & $26(24.5)$ & $80(75.5)$ & \\
\hline
\end{tabular}

We calculated the agreement between HPV DNA and p16INK4A expression results, and the tests showed a concordance of $91.2 \%$. The Kappa score was 0.726 , indicating substantial agreement to the Landis-Koch reference value. 


\section{Discussion}

Common risk factors for HNSCC are alcohol consumption, smoking, being over 60 and living in today's developed Western countries [8]. In recent years, the rate of HPV-positive HNSCC cases, especially HPV-associated OPSCC, has rapidly increased in the USA [26]. In the 20-year period from 1984 to 2004, the incidence of HPV-positive OPSCC has drastically increased by $225 \%$ [27]. In our study, the highest HPV prevalence was found in OPSCC, especially in the palatine tonsils, and HPV DNA was also observed in cancers of the oral cavity. Our observations strongly suggest that there may be an important relationship between HPV infection and HPV-associated carcinogenesis in the oropharynx, especially in the region of the palatine tonsils. The results of our study underpin the results of previous international studies [28] and greatly contribute to the global data on the prevalence of HPV DNA in malignancies in the head and neck region. We did not observe a complete overlap between HPV DNA PCR and p16INK4A immunohistochemical staining results. p16INK4A positivity was observed in 16 of 23 samples (69.5\%) with HPV DNA positivity. In real-time quantitative PCR tests that were carried out in the study, there were two p16INK4A positive samples that were negative for HPV DNA. IHC p16INK4A-positivity and HPV DNA positivity correlates significantly in HNSCC. However, there may still be a discrepancy rate of approximately $10 \%$ between these two measurements [29]. To date, it is unclear whether these discrepancies are even real, or if these are artificial discrepancies due to limitations in specificity/sensitivity [30]. Previous studies have reported that individuals with HPV-positive / p16INK4A-negative and HPV-negative / p16INK4A-positive HSNCC show different prognoses and indicated the existence of a p16INK4A-associated HNSCC subgroup independent of HPV status [30]. HPV-positive OPSCC patients in the present study accounted for $40.6 \%$ cases among non-smokers, $27.9 \%$ among non-alcoholic and $35.7 \%$ among 19-60-year-old individuals. Although HPV-associated tumorigenesis seems statistically to be only age-related, HPV-positive HSNCC are more common in patients who do not smoke and do not drink alcohol at young ages, which is in line with previously published studies [31,32]. Previous research has shown that high-risk HPV types dominate in HPV-positive HNSCCs. Baboci et al. [33] found that 95\% of HPV-positive HNSCCs carried HPV16 sequences, while the only other HPV type identified was high-risk type was HPV58. Ni et al. [34] demonstrated high-risk HPV types in $26.4 \%$ of tumor samples, with the vast majority (71\%) being infected with HPV16. Other high-risk types included HPV18, HPV33 and HPV82. In the present study, we predominantly found the high-risk HPV types 16, 18, 45 and 82 in HPV-positive tumors. In contrast, we did not detect any low-risk HPV types in the tumor samples. These results suggest that, among the various HPV types, HPV16 plays a pivotal role in HNSCC development and particularly in OPSCC tumorigenesis. Smoking is a major risk factor for the development of HNSCC. Smoking has decreased in recent years, which is paralleled by a decrease in the incidence of smokingrelated diseases in developed countries [35]. Recent studies have shown that the frequency of OPSCC increases among both HPV16-positive and HPV16-negative smokers [36]. In Turkey, $46.1 \%$ of the male population uses tobacco, whereas only $15.7 \%$ of women are smokers. Moreover, Turkey is one of the countries with the highest mortality rate due to smoking worldwide, with $26.1 \%$ of men and $7.6 \%$ of women developing fatal conditions due to tobacco abuse $[37,38]$. Although the vast majority of patients who participated in our study were smokers, the incidence of HPV in non-smoking patients was observed to be higher than those who are light and heavy smokers. Initially, studies on HNSCC in Turkey were conducted as local studies with a low number of patients [18,19]. By performing in situ hybridization against HPV DNA, Umudum et al. (2005) found an HPV prevalence of $15 \%$ in HNSCC studied in Ankara [19]. In a previous study conducted in Istanbul on 81 OPSCC biopsies HPV DNA was detected by PCR in $52 \%$ and HPV16 was observed in $86 \%$ of the positive tested tumors [21]. Since p16INK4A staining was not performed, the real HPV prevalence remains unanswered in these studies. The data from the current study suggest that HPV infection accounts for about $1 / 4$ th of the HNSCC cases in patients from Istanbul. According to our data on OPSCC, the frequency of HPV was found to be $27.8 \%$. 
HPV16 was observed in $85 \%$ of the HPV DNA positive cases and is therefore an important etiological agent in OPSCC development in Turkey.

There are several limitations to the current study. First, we have no data on the sexual behavior of the patients. In addition, since a commercial kit was used in the current study, HPV types that were not included in the kit could not be examined. Finally, our study was conducted using samples from two centers in Istanbul, and the results may therefore not be representative of Turkey.

In a study investigating the frequency of HPV in tonsil tumor-free tissues in children and young adults, the prevalence was detected to be at about $6.3 \%$, indicating that HPV can settle in the mouth at a very early age [39]. Considering that Turkey has a young population who, in general, practices oral sex [40], HPV vaccines known to reduce oral HPV prevalence may represent the most effective tool for the prevention of HPV-induced HNSCC. In Turkey, HPV vaccination is not included in the National immunization programme. The inclusion of HPV vaccines in the national vaccination schedule undoubtedly would not only contribute to the prevention of cervical cancers but also aid in halting the rise in HPV-related HNSCC.

\section{Materials and Methods}

\subsection{Study Population}

This study was approved by the Ethics Committee of the Dentistry Faculty, Istanbul University (Approval Number: 2015/9-6). Informed consent was obtained from all patients who were accepted to be enrolled in the study. This study included a total of 106 patients (78 male/28 female) with a clinical diagnosis of HNSCC. In this study, fresh or frozen biopsies from patients with histologically confirmed HNSCC were collected at the Head and Neck Surgery, Istanbul Faculty of Medicine, as well as the Sisli Hamidiye Etfal Training and Research Hospital, between January 2015 and January 2019. HNSCC biopsies were immediately transferred to and stored at $-80{ }^{\circ} \mathrm{C}$ in Copan eNAT specimen transport medium (Copan Diagnostics Inc., Brescia, Italy), followed by the extraction of genomic DNA. Viral DNA was isolated from $300 \mu \mathrm{L}$ of patient oral biopsies using the GeneAll Ribospin vRD Viral RNA/DNA Extraction Kit (GeneAll Biotechnology Co., Seoul, Korea) according to manufacturer's instructions.

\subsection{HPV Genotyping and $p 16 I N K 4 a$ Staining}

Anyplex ${ }^{\mathrm{TM}}$ II HPV28 kit was performed according to manufacturer's instructions (Seegene, Seoul, Korea), using $5 \mu \mathrm{L}$ DNA in each of the two $20 \mu \mathrm{L}$ reaction mixtures with primer sets A or B, respectively [41]. The Anyplex ${ }^{\mathrm{TM}}$ II HPV28 kit semi-quantitatively distinguishes $28 \mathrm{HPV}$ genotypes (namely types 6, 11, 16, 18, 26, 31, 33, 35, 39, 40, 42-45, $51-54,56-59,61,66,68-70,73$ and 82) in two reactions that can be resolved on the CFX96 real-time PCR device (Bio-Rad, Hercules, CA, USA) simultaneously, thus allowing the identification of the vast majority of clinically relevant HPV types. Cycling conditions encompassed an incubation period of $4 \mathrm{~min}$ at $50{ }^{\circ} \mathrm{C}$ (to activate the uracil DNA glycosylase in order to prevent contamination), denaturation for $15 \mathrm{~min}$ at $95^{\circ} \mathrm{C}$, followed by 50 cycles $/ 30 \mathrm{~s}$ at $95^{\circ} \mathrm{C}, 1 \mathrm{~min}$ at $60^{\circ} \mathrm{C}$ and $30 \mathrm{~s}$ at $72{ }^{\circ} \mathrm{C}$. The fluorescence levels were constantly measured as the temperature increased. Melting temperature analysis conditions included cooling to $55^{\circ} \mathrm{C}$, holding at $55^{\circ} \mathrm{C}$ for $30 \mathrm{~s}$ and heating from $55^{\circ} \mathrm{C}$ to $85^{\circ} \mathrm{C}\left(5 \mathrm{~s} / 0.5^{\circ} \mathrm{C}\right)$, which was measured after PCR cycles 30, 40 and 50. DNA of the HPV L1 gene and a human housekeeping gene (human beta-globin) were co-amplified simultaneously as an internal control. Data interpretation was performed with the Anyplex software (Seegene, Seoul, Korea) according to the manufacturer's instructions. p16INK4A expression was detected on whole tumor sections using the CINtec Histology kit (Roche mtm Laboratories, Mannheim, Germany) according to antibody suppliers' and standard protocols [42]. 


\subsection{Statistics}

Statistical analysis was performed using Pearson chi-square and Fisher's exact test. Differences with a $p$ value $<0.05$ were considered significant. Concordance between HPV DNA and p16 expression results was assessed by Cohen's kappa score.

Author Contributions: Conceptualization, F.K. and B.A.; methodology, F.K. and A.Q.; software, M.O.K. and F.K.; validation, M.O.K., F.K. and S.Ç.; formal analysis, M.O.K.; investigation, M.O.K., F.K., S.Ç., B.K.Y., S.Ö.H., I.Y. and A.Q.; resources, I.Y., B.B., S.Ö.H. and A.Q.; data curation, M.O.K., F.K. and B.A.; writing-original draft preparation, M.O.K., F.K. and B.A.; writing-review and editing, M.O.K., B.A. and A.Q.; visualization, M.O.K. and F.K.; supervision, A.A., K.D. and B.A.; project administration, B.A. and F.K.; funding acquisition, F.K. and B.A. All authors have read and agreed to the published version of the manuscript.

Funding: This research was funded by Istanbul University, Scientific Research Projects Coordination Unit (Research ID: 2989/2015) and by intramural funds of the Faculty of Medicine, University of Cologne (Cologne Fortune no. 2680-9159-01).

Institutional Review Board Statement: The study was conducted according to the guidelines of the Declaration of Helsinki and approved by the Ethics Committee of the Dentistry Faculty, Istanbul University (Approval Number: 2015/9-6).

Informed Consent Statement: Informed consent was obtained from all subjects involved in the study.

Conflicts of Interest: The authors declare no conflict of interest.

\section{References}

1. Hübbers, C.U.; Akgül, B. HPV and cancer of the oral cavity. Virulence 2015, 6, 244-248. [CrossRef]

2. Vigneswaran, N.; Williams, M.D. Epidemiologic trends in head and neck cancer and aids in diagnosis. Oral Maxillofac Surg. Clin. N. Am. 2014, 26, 123-141. [CrossRef]

3. Ndiaye, C.; Mena, M.; Alemany, L.; Arbyn, M.; Castellsagué, X.; Laporte, L.; Bosch, F.X.; de Sanjosé, S.; Trottier, H. HPV DNA, E6/E7 mRNA, and p16INK4a detection in head and neck cancers: A systematic review and meta-analysis. Lancet Oncol. 2014, 15, 1319-1331. [CrossRef]

4. Marur, S.; Forastiere, A.A. Head and Neck Squamous Cell Carcinoma: Update on Epidemiology, Diagnosis, and Treatment. Mayo Clin. Proc. 2016, 91, 386-396. [CrossRef]

5. Fakhry, C.; D'souza, G. Discussing the diagnosis of HPV-OSCC: Common questions and answers. Oral Oncol. 2013, 49, 863-871. [CrossRef]

6. Taberna, M.; Mena, M.; Pavon, M.A.; Alemany, L.; Gillison, M.L.; Mesia, R. Human papillomavirus-related oropharyngeal cancer. Ann. Oncol. 2017, 28, 2386-2389. [CrossRef] [PubMed]

7. D'Souza, G.; Kreimer, A.R.; Viscidi, R.; Pawlita, M.; Fakhry, C.; Koch, W.M.; Westra, W.H.; Gillison, M.L. Case-Control Study of Human Papillomavirus and Oropharyngeal Cancer. N. Engl. J. Med. 2007, 356, 1944-1956. [CrossRef]

8. Chow, L.Q.M. Head and neck cancer. N. Engl. J. Med. 2020, 382, 60-72. [CrossRef] [PubMed]

9. Lehtinen, T.; Elfström, K.M.; Mäkitie, A.; Nygård, M.; Vänskä, S.; Pawlita, M.; Dillner, J.; Waterboer, T.; Lehtinen, M. Elimination of HPV-associated oropharyngeal cancers in Nordic countries. Prev. Med. 2021, 144, 106445. [CrossRef] [PubMed]

10. Edelstein, Z.R.; Schwartz, S.M.; Hawes, S.; Hughes, J.P.; Feng, Q.; Stern, M.E.; O'Reilly, S.; Lee, S.K.; Fu Xi, L.; Koutsky, L.A. Rates and determinants of oral human papillomavirus infection in young men. Sex. Transm. Dis. 2012, 39, 860-867. [CrossRef] [PubMed]

11. Schwartz, S.M.; Daling, J.R.; Madeleine, M.M.; Doody, D.R.; Fitzgibbons, E.D.; Wipf, G.C.; Carter, J.J.; Mao, E.J.; Huang, S.; Beckmann, A.M.; et al. Oral Cancer Risk in Relation to Sexual History and Evidence of Human Papillomavirus Infection. J. Natl. Cancer Inst. 1998, 90, 1626-1636. [CrossRef]

12. Michaud, D.S.; Langevin, S.M.; Eliot, M.; Nelson, H.H.; Pawlita, M.; McClean, M.D.; Kelsey, K.T. High-risk HPV types and head and neck cancer. Int. J. Cancer 2014, 135, 1653-1661. [CrossRef] [PubMed]

13. Hoffmann, M.; Ihloff, A.S.; Görögh, T.; Weise, J.B.; Fazel, A.; Krams, M.; Rittgen, W.; Schwarz, E.; Kahn, T. p16INK4a overexpression predicts translational active human papillomavirus infection in tonsillar cancer. Int. J. Cancer 2010, 127, 1595-1602. [CrossRef]

14. El-Naggar, A.K.; Westra, W.H. p16 expression as a surrogate marker for HPV-related oropharyngeal carcinoma: A guide for interpretative relevance and consistency. Head Neck 2012, 34, 459-461. [CrossRef]

15. Rasmussen, J.H.; Grønhøj, C.; Håkansson, K.; Friborg, J.; Andersen, E.; Lelkaitis, G.; Klussmann, J.P.; Wittekindt, C.; Wagner, S.; Vogelius, I.R.; et al. Risk profiling based on p16 and HPV DNA more accurately predicts location of disease relapse in patients with oropharyngeal squamous cell carcinoma. Ann. Oncol. 2019, 30, 629-636. [CrossRef] [PubMed] 
16. Fakhry, C.; Lacchetti, C.; Rooper, L.M.; Jordan, R.C.; Rischin, D.; Sturgis, E.M.; Bell, D.; Lingen, M.W.; Harichand-Herdt, S.; Thibo, J.; et al. Human Papillomavirus Testing in Head and Neck Carcinomas: ASCO Clinical Practice Guideline Endorsement of the College of American Pathologists Guideline. J. Clin. Oncol. 2018, 36, 3152-3161. [CrossRef] [PubMed]

17. Turkish Cancer Statistics_-2017, General Directorate of Public Health, Turkish Ministry of Health. 2021. Available online: https: //hsgm.saglik.gov.tr/depo/birimler/kanser-db/istatistik/Turkiye_Kanser_Istatistikleri_2017.pdf (accessed on 11 November 2021).

18. Yaltırık, M.; Özveren, A.; Alatlı, C.; Büyükakyüz, H.N. Detection of human papilloma virus in benign, malignant and precancerous lesions of oral mucosa by in situ hybridization. Turk. J. Med. Sci. 2001, 31, 509-515.

19. Umudum, H.; Rezanko, T.; Dag, F.; Dogruluk, T. Human papillomavirus genome detection by in situ hybridization in fine-needle aspirates of metastatic lesions from head and neck squamous cell carcinomas. Cancer Cytopathol. 2005, 105, 171-177. [CrossRef]

20. Tural, D.; Elicin, O.; Batur, S.; Arslan, D.; Oz, B.; Serdengecti, S.; Uzel, Ö. Increase in the rate of HPV positive oropharyngeal cancers during 1996-2011 in a case study in Turkey. Asian Pac. J. Cancer Prev. 2013, 14, 6065-6068. [CrossRef]

21. Tural, D.; Elicin, O.; Batur, S.; Arslan, D.; Oz, B.; Serdengecti, S.; Uzel, Ö. Human papillomavirus is independent prognostic factor on outcome of oropharyngeal squamous cell carcinoma. Tumour. Biol. 2013, 34, 3363-3369. [CrossRef]

22. Gungor, A.; Cincik, H.; Baloglu, H.; Cekin, E.; Dogru, S.; Dursun, E. Human papilloma virus prevalence in laryngeal squamous cell carcinoma. J. Laryngol. Otol. 2007, 121, 772-774. [CrossRef]

23. Kaya, H.; Kotiloğlu, E.; Inanli, S.; Ekicioğlu, G.; Bozkurt, S.U.; Tutkun, A.; Küllü, S. Prevalence of human papillomavirus (HPV) DNA in larynx and lung carcinomas. Pathologica 2001, 93, 531-534.

24. Erkul, E.; Yilmaz, I.; Narli, G.; Babayigit, M.A.; Gungor, A.; Demirel, D. The presence and prognostic significance of human papillomavirus in squamous cell carcinoma of the larynx. Eur. Arch. Otorhinolaryngol. 2017, 274, 2921-2926. [CrossRef]

25. Lewis, J.S., Jr.; Beadle, B.; Bishop, J.A.; Chernock, R.D.; Colasacco, C.; Lacchetti, C.; Moncur, J.T.; Rocco, J.W.; Schwartz, M.R.; Seethala, R.R.; et al. Human Papillomavirus Testing in Head and Neck Carcinomas: Guideline from the College of American Pathologists. Arch. Pathol. Lab. Med. 2018, 142, 559-597. [CrossRef] [PubMed]

26. Pytynia, K.B.; Dahlstrom, K.R.; Sturgis, E.M. Epidemiology of HPV-associated oropharyngeal cancer. Oral Oncol. 2014, 50, 380-386. [CrossRef]

27. Chaturvedi, A.K.; Engels, E.A.; Pfeiffer, R.M.; Hernandez, B.Y.; Xiao, W.; Kim, E.; Jiang, B.; Goodman, M.T.; Sibug-Saber, M.; Cozen, W.; et al. Human papillomavirus and rising oropharyngeal cancer incidence in the United States. J. Clin. Oncol. 2011, 29, 4294-4301. [CrossRef] [PubMed]

28. Castellsagué, X.; Alemany, L.; Quer, M.; Halec, G.; Quirós, B.; Tous, S.; Clavero, O.; Alòs, L.; Biegner, T.; Szafarowski, T.; et al. HPV Involvement in Head and Neck Cancers: Comprehensive Assessment of Biomarkers in 3680 Patients. J. Natl. Cancer Inst. 2016, 108, djv403. [CrossRef]

29. Coordes, A.; Lenz, K.; Qian, X.; Lenarz, M.; Kaufmann, A.M.; Albers, A.E. Meta-analysis of survival in patients with HNSCC discriminates risk depending on combined HPV and p16 status. Eur. Arch. Otorhinolaryngol. 2016, 273, 2157-2169. [CrossRef]

30. Albers, A.E.; Qian, X.; Kaufmann, A.M.; Coordes, A. Meta-analysis: HPV and p16 pattern determines survival in patients with HNSCC and identifies potential new biologic subtype. Sci. Rep. 2017, 7, 16715. [CrossRef] [PubMed]

31. Pinatti, L.M.; Walline, H.M.; Carey, T.E. Human Papillomavirus Genome Integration and Head and Neck Cancer. J. Dent. Res. 2018, 97, 691-700. [CrossRef] [PubMed]

32. Mulder, F.J.; Pierssens, D.D.C.G.; Baijens, L.W.J.; Kremer, B.; Speel, E.J.M. Evidence for different molecular parameters in head and neck squamous cell carcinoma of nonsmokers and nondrinkers: Systematic review and meta-analysis on HPV, p16, and TP53. Head Neck 2021, 43, 303-322. [CrossRef]

33. Baboci, L.; Holzinger, D.; Boscolo-Rizzo, P.; Tirelli, G.; Spinato, R.; Lupato, V.; Fuson, R.; Schmitt, M.; Michel, A.; Halec, G.; et al. Low prevalence of HPV-driven head and neck squamous cell carcinoma in North-East Italy. Papillomavirus Res. 2016, 2, 133-140. [CrossRef] [PubMed]

34. Ni, G.; Huang, K.; Luan, Y.; Cao, Z.; Chen, S.; Ma, B.; Yuan, J.; Wu, X.; Chen, G.; Wang, T.; et al. Human papillomavirus infection among head and neck squamous cell carcinomas in southern China. PLoS ONE 2019, 14, e0221045. [CrossRef]

35. Thun, M.; Peto, R.; Boreham, J.; Lopez, A.D. Stages of the cigarette epidemic on entering its second century. Tob. Control. 2012, 21, 96-101. [CrossRef]

36. Anantharaman, D.; Muller, D.C.; Lagiou, P.; Ahrens, W.; Holcátová, I.; Merletti, F.; Kjærheim, K.; Polesel, J.; Simonato, L.; Canova, C.; et al. Combined effects of smoking and HPV16 in oropharyngeal cancer. Int. J. Epidemiol. 2016, 45, 752-761. [CrossRef]

37. Özer, N.; Kılıçkap, M.; Tokgözoğlu, L.; Göksülük, H.; Karaaslan, D.; Kayıkçığlu, M.; Yılmaz, M.B.; Barçın, C.; Abacı, A.; Şahin, M. Data on smoking in Turkey: Systematic review, meta-analysis and meta-regression of epidemiological studies on cardiovascular risk factors. Turk. Kardiyol. Dern Ars. 2018, 46, 602-612. [CrossRef]

38. Ipek, Ö.; Ipek, E. Türkiye'de Sigara Yasaklarının Sigara Kullanımı Üzerindeki Etkisi. Ank. Hacı Bayram Veli Univ. J. Fac. Econ. Adm. Sci. 2020, 179-190.

39. Baloğlu, H.; Küçükodaci, Z.; Güngör, A.; Haholu, A.; Cincik, H.; Yaşayan, G.; Örsçelik, S.G. Human papilloma virus prevalence in hyperplastic tonsils and adenoids in children and young adults. Turkiye Klin. J. Med. Sci. 2010, 30, 528-532. [CrossRef]

40. Nazik, F.; Omaç Sönmez, M.; Akben, M. Gender, sexual experiences and sexual behavioural differences in Turkish university students. J. Biosoc. Sci. 2021, 53, 471-480. [CrossRef] 
41. Chun, J.Y.; Kim, K.J.; Hwang, I.T.; Kim, Y.J.; Lee, D.H.; Lee, I.K.; Kim, J.K. Dual priming oligonucleotide system for the multiplex detection of respiratory viruses and SNP genotyping of CYP2C19 gene. Nucleic Acids Res. 2007, 35, e40. [CrossRef] [PubMed]

42. Klussmann, J.P.; Gültekin, E.; Weissenborn, S.J.; Wieland, U.; Dries, V.; Dienes, H.P.; Eckel, H.E.; Pfister, H.J.; Fuchs, P.G. Expression of p16 Protein Identifies a Distinct Entity of Tonsillar Carcinomas Associated with Human Papillomavirus. Am. J. Pathol. 2003, 162, 747-753. [CrossRef] 